Document downloaded from:

http://hdl.handle.net/10251/107396

This paper must be cited as:

Escobar Lanzuela, N.; Ramírez-Sanz, C.; Chueca, P.; Molto Garcia, E.; Sanjuán Pellicer, N. (2017). Multiyear Life Cycle Assessment of switchgrass (Panicum virgatum L.) production in the Mediterranean region of Spain: A comparative case study. Biomass and Bioenergy. 107:74-85. doi:10.1016/j.biombioe.2017.09.008

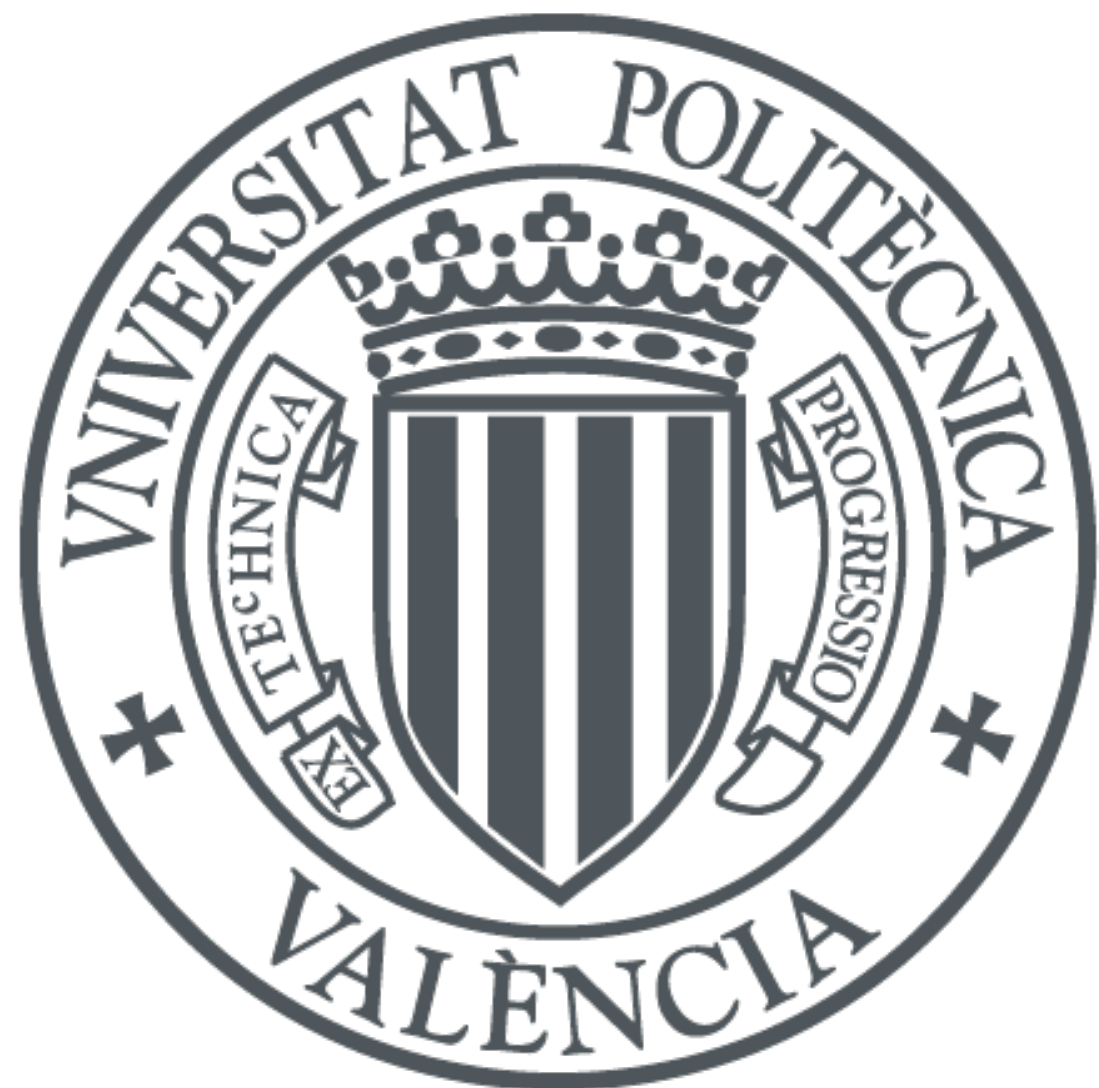

The final publication is available at

https://doi.org/10.1016/j.biombioe.2017.09.008

Copyright Elsevier

Additional Information 


\title{
Multiyear Life Cycle Assessment of switchgrass (Panicum virgatum L.) production in the Mediterranean region of Spain: A comparative case study
}

\author{
Neus Escobar ${ }^{a, \star}$, Clara Ramírez ${ }^{\mathrm{a}}$, Patricia Chuecab ${ }^{\mathrm{b}}$ Enrique Moltób ${ }^{b}$ Neus Sanjuán ${ }^{\mathrm{a}}$ \\ aGrup ASPA. Departament de Tecnologia d'Aliments, Edifici 3F, Universitat Politècnica de \\ València, Camí de Vera s/n, 46022, València (Spain) \\ bInstituto Valenciano de Investigaciones Agrarias (IVIA), Carretera Moncada-Náquera, km 4.5, \\ 46113 Moncada, Valencia (Spain)
}

*Corresponding author. Tel.: +34 963879 366; fax: +34 963879 839. E-mail address: neueslan@etsia.upv.es, neueslan@gmail.com (N. Escobar)

\begin{abstract}
An LCA of switchgrass production in the Mediterranean region of Spain is carried out, from a cradle-to-farm gate perspective. Experimental plots were previously established in two locations, Moncofar and Orihuela, providing inventory data for 2010-2013. This allowed for the environmental performance to be evaluated throughout a 4-year cycle, considering different sources of variability. The functional unit is $1 \mathrm{t}$ of switchgrass (dry basis) for electricity generation. Besides typical impact categories, blue and green water consumption impacts are also addressed by using watershed characterization factors. In 2010, the production in Orihuela is more input-intensive than in Moncofar, while the biomass yield is lower, causing greater impacts (959.4 vs. $95.9 \mathrm{~kg}$ of $\mathrm{CO}_{2}$ eq $\mathrm{t}^{-1}$ for climate change or $19.1 \mathrm{vs.} 4.7 \mathrm{~kg}$ of Fe-eq. $\mathrm{t}^{-1}$ for metal depletion). In the subsequent years, the yields are higher in Orihuela, hence Moncofar performs worse for some specific impact categories (43.9 vs. $28.5 \mathrm{CO}_{2}-\mathrm{eq} \cdot \mathrm{t}^{-1}$ or $8.0 \mathrm{vs} .2 .4 \mathrm{~kg}$ of Feeq $\cdot \mathrm{t}^{-1}$ in 2011). Due to larger irrigation doses in Orihuela, the blue water impact is always higher than that in Moncofar (on average, 1243 vs. $277 \mathrm{~m}^{3}$ ecosystem-eq. water $\cdot \mathrm{t}^{-1}$ ). The green water impact is greater in the latter, except for the first year (on average, 6.9 vs. $53.0 \mathrm{~m}^{3}$ ecosystem-eq. water $\cdot \mathrm{t}^{-1}$ ). Overall, both locations deliver sufficient greenhouse gas savings throughout the life cycle, in compliance with the EU requirements for bio-electricity production. However, results show that ad hoc decisions on crop management are critical to the environmental impact, evidencing the importance of considering a multi-year LCA approach.
\end{abstract}

Keywords: biomass, crop management, environmental impact, perennial crops, variability, water scarcity

\section{Introduction}

Energy and climate policies around the world have been fostering biomass consumption in the last decades. Biomass currently represents the most important renewable energy source in the EU-28, accounting for $64 \%$ of the primary renewables production, although this share is lower in Spain (38\%) [1], in spite of the wide availability of plant based materials [2]. Biomass future expansion depends on agricultural and technical progress, and policy support [3-5]. In order to prevent competition for food, recent policies encourage transition from grain to lignocellulosic, cellulosic, and waste biomass, under the lead of the EU and the United States (US). C4 plants are considered serious candidates for both ethanol production and power 
generation [6-8], since these are fast growing species that can succeed in a wide range of geographic areas. Efficient production of bioenergy from such perennial grasses requires the choice of the most appropriate grass species for the given ecological climatic conditions [9]. However, there are limitations that will influence the types of energy cropping systems that will be sustainable in the future, the main limitation being the amount of land area and agronomic resources than can be made available for dedicated energy crops [10].

Switchgrass (Panicum virgatum L.) is a warm-season C4 grass and, as such, is capable of generating large quantities of biomass, even in resource limited environments [10]. Due to its high adaptability to different soils and climates, switchgrass can potentially be grown in cold and warm regions of EU, even under semiarid conditions $[6,9,11,12]$. Despite the number of studies analysing the adaptability and biomass productivity of switchgrass varieties in different geographical areas $[9,11,13,14]$, the switchgrass cultivation at farm scale has hardly begun in the EU [15].

Besides the large range of geographic adaptation and the high conversion efficiency [16], many other reasons are given for using switchgrass for bioenergy production, i.e. low production costs, potential for carbon storage in soil, high nitrogen use efficiency and low nutrient requirements, and high water use efficiency [17-19]. This is why switchgrass and other perennial grasses are generally anticipated positive environmental impact. Moreover, given the suitability to grow in marginal lands, these crops are expected to generate lower indirect land use change (ILUC), although further studies are needed not to underestimate overall GHG emissions [20]. Life Cycle Assessment (LCA) is considered a robust and comprehensive method to evaluate these possible environmental benefits as compared to reference fossil alternatives, not only in terms of GHG savings [21,22] but also in terms of other critical impacts such as eutrophication or acidification [23-25] or those from water consumption [26,27]. ILUC is, however, an exception since it is the result of market dynamics triggered by the displacement of previous food crops and there is no consensus on the methodology to apply for its quantification. Similarly, [26] point to the need for further research on the trade-offs between biofuel water and carbon footprints, especially if they are meant to be produced in water-stressed areas. Studies such as those from [28-30] show that there is still a great uncertainty on the impacts generated by bioenergy, depending on the feedstock, edaphoclimatic conditions of the site, and agricultural practices.

In general, higher yields improve the environmental performance of agricultural products, including bioenergy [31-33]. However, cultivation and management practices that increase productivity can also increase overall emissions, e.g. increase in fertilizer rates entails larger GHG emissions from fertilizer production and application [24]. Therefore, an in-depth evaluation of such factors, as well as their interactions, is necessary to refine agricultural practices to both maximize yields and mitigate impacts from switchgrass [20]. In this process, it must be borne in mind that agricultural systems show a significant variability due to the range of farming practices, which can be affected not only by spatial (region where the crop is carried out) and temporal (crop age and climate) aspects, but also by the farmer's personal choices $[34,35]$ and even technological innovation [36]. Regarding temporal variability, most agricultural LCAs focus on one year of full production, neglecting the low productive phases due to the system's immaturity and to plant senescence $[28,37,38]$, and also changes in annual 
crop productivity associated to climatic variability from year to year $[35,38]$. These authors highlight the importance of taking the whole life cropping cycle into account when studying perennial crops, especially in short cycle crops.

The goal of this study was to estimate the environmental impacts from switchgrass cultivated in two different Mediterranean locations of Spain (both in the region of Comunidad Valenciana). This is a water-scarce region where bioenergy can be an interesting alternative to be grown on set-aside land, hence contributing to farmers' income. This study arises from the project of [39], whose aim was to assess the performance of different lignocellulosic crops for energy generation by combustion in that very region. The two locations selected for the present study represent different edaphoclimatic conditions, which translate, in turn, into differences in terms of water availability, water use, agricultural practices in general, and biomass productivity. In order to understand the influence of this variability throughout the cropping cycle, the impacts were evaluated for four production years, including the crop establishment. Results were further used to quantify the GHG benefits brought about by the potential electricity output when considering both temporal and spatial variability in the agricultural system. The ultimate aim was to identify hotspots in agricultural biomass production under Mediterranean conditions, as well as options for crop management optimization in a region where there is little experience on switchgrass cultivation.

\section{Methods}

The LCA was carried out according to the ISO standards (ISO 14040:2006 and ISO 14044:2006).

\subsection{Goal and scope definition}

The impact quantification was based on experimental data obtained from February 2010 to December 2013. The temporal scope of the present study is in line with the duration of the aforementioned project, covering a 4-year cycle [39]. Data was gathered from experimental plots established in the municipalities of Moncofar (Castellón) (X: 742561.8; Y: 4410136.5) and Orihuela (Alicante) (X: 695011.56; Y: 4198478.3), north and south of the city of Valencia, respectively. The most important edaphoclimatic features of the two locations are highlighted in Tables 1 and 2, while meteorological data for the period is shown in Figure 1.

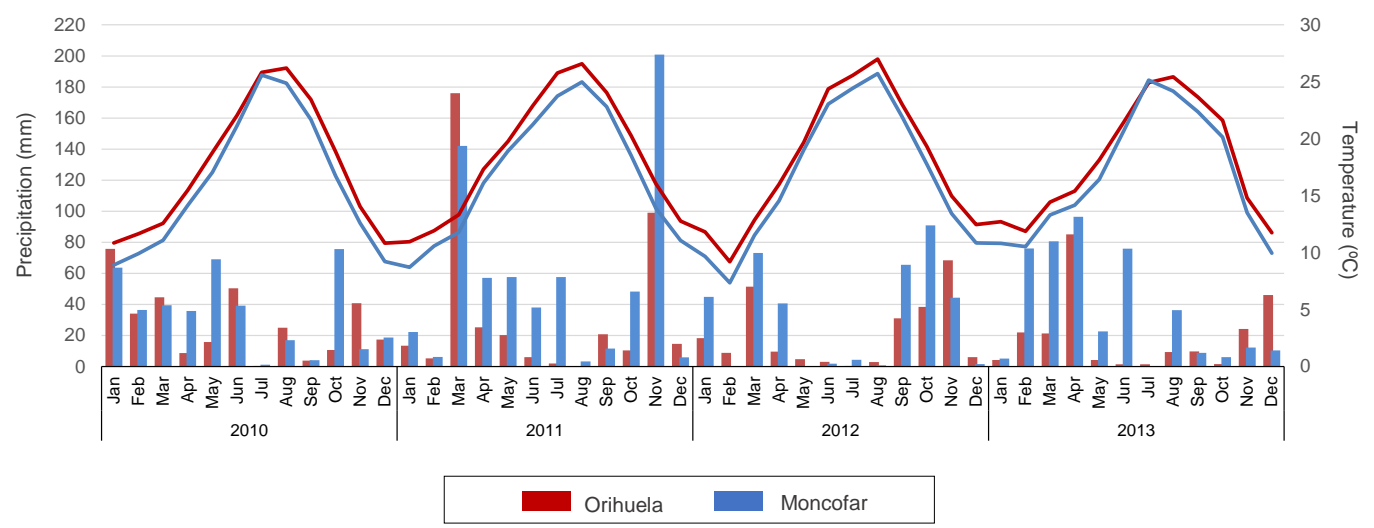

Figure 1 . Monthly precipitation $(\mathrm{mm})$-on the bar chart- and temperature $\left({ }^{\circ} \mathrm{C}\right)$-on the line chart- in both Orihuela and Moncofar, gathered from the meteorological stations of Pilar de la Horadada and Nules, respectively [41]. 
Table 1. Climatic parameters of the two locations where switchgrass experimental plots were established.

\begin{tabular}{|l|c|c|}
\hline \multirow{2}{*}{} & \multicolumn{2}{|c|}{ Location } \\
\cline { 2 - 3 } & Moncofar & Orihuela \\
\hline Average annual rainfall $(\mathrm{mm})$ & $500-600$ & $300-400$ \\
\hline Average annual temperature $\left({ }^{\circ} \mathrm{C}\right)$ & $15-17$ & $17-19$ \\
\hline Cold period length (months) & $3-4.5$ & $3-4.5$ \\
\hline Warm period length (months) & $1.5-2$ & $2.5-3$ \\
\hline $\begin{array}{l}\text { Annual reference evapotranspiration }\left(\mathrm{ET}_{0}\right) \\
\text { (mm) }\end{array}$ & $1,000-1,060$ & $1,120-1,180$ \\
\hline Martonne aridity index & $\begin{array}{c}\text { Semi-arid } \\
\text { (Mediterranean) }\end{array}$ & Arid (semi-desert) \\
\hline $\begin{array}{l}\text { Aridity index: precipitation-potential } \\
\text { evapotranspiration ratio (P/ET) }\end{array}$ & 0.40 & 0.25 \\
\hline
\end{tabular}

Table 2. Edaphic parameters of the two locations where switchgrass experimental plots were established, expressed as mass fraction according to USDA [40].

\begin{tabular}{|r|c|c|}
\hline & Moncofar & Orihuela \\
\hline Texture & & \\
\hline Sand (\%) & 57 & 80 \\
\hline Clay (\%) & 16 & 20 \\
\hline Silt (\%) & 27 & 0 \\
\hline $\mathrm{pH}$ & 7.8 & 8.7 \\
\hline $\begin{array}{l}\text { Organic } \\
\text { material (\%) }\end{array}$ & 1.0 & 0.9 \\
\hline
\end{tabular}

In LCA, the system data is related to a functional unit (FU), whose definition depends on the function performed by the process under study. In this case, the main function of the agricultural system is to deliver biomass as an intermediate product of electricity production. Thus, the FU was defined as 1 tonne of switchgrass on a dry basis, from a cradle-to-farm gate perspective. The mass-based FU is adequate in this case because the scope is the primary production of biomass [36], while it is easy to comprehend [33]. Besides, it captures the effect of different biomass yields on the impacts, according to the goal of the study, which do not only arise from the variability in agricultural practices. On the contrary, an area-based FU (e.g. 1 ha) is recommended when focusing on the analysis of land uses; it is especially interesting to compare biomass cropping systems that entail different species [29,42-44]. It must be pointed out, though, that a mass-based FU does not reflect biomass quality. This is why data on the chemical composition of the switchgrass produced in the assessed subplots is shown in Table 3, in order to contribute to the biomass characterization. 
Table 3. Physicochemical characterization of the biomass obtained from the Alamo cultivar in the two locations, by following ISO EN standards for solid biofuels [45].

\begin{tabular}{|l|c|c|c|c|}
\hline & Units & Moncofar & Orihuela & Measuring procedure \\
\hline $\begin{array}{l}\text { Ash content (at } 550 \\
\left.\text { and } 900^{\circ} \mathrm{C}\right)\end{array}$ & $\begin{array}{c}\text { mass fraction of } \\
\text { dry biomass }\end{array}$ & $5.4 \pm 0.4$ & $5.6 \pm 1$ & ISO 18122:2015; 18123:2015 \\
\hline $\mathrm{C}$ content & $\begin{array}{c}\text { mass fraction of } \\
\text { dry biomass }\end{array}$ & $46.3 \pm 0.5$ & $45.8 \pm 0.8$ & ISO 16948:2015 \\
\hline $\mathrm{H}$ content & $\begin{array}{c}\text { mass fraction of } \\
\text { dry biomass }\end{array}$ & $6 \pm 0.07$ & $5.9 \pm 0.07$ & ISO 16948:2015 \\
\hline $\mathrm{N}$ content & $\begin{array}{c}\text { mass fraction of } \\
\text { dry biomass }\end{array}$ & $0.60 \pm 0.1$ & $0.42 \pm 0.3$ & ISO 16948:2015 \\
\hline $\mathrm{Cl}$ content & $\begin{array}{c}\text { mass fraction of } \\
\text { dry biomass }\end{array}$ & $0.76 \pm 0.2$ & $0.70 \pm 0.3$ & ISO 16994:2015 \\
\hline S content & $\begin{array}{c}\text { mass fraction of } \\
\text { dry biomass }\end{array}$ & $0.09 \pm 0.01$ & $0.07 \pm 0.02$ & ISO 16994:2015 \\
\hline $\begin{array}{l}\text { Oass fraction of } \\
\text { dry biomass }\end{array}$ & $40.9 \pm 0.6$ & $41.6 \pm 1$ & ISO 16993:2015 \\
\hline $\begin{array}{l}\text { Gross calorific value } \\
\text { at constant volume } \\
(\mathrm{GCV}, \mathrm{d})\end{array}$ & $\mathrm{MJ} / \mathrm{kg}$ & $18.6 \pm 0.4$ & $18.4 \pm 0.3$ & EN 14918:2009 \\
\hline $\begin{array}{l}\text { Net calorific value at } \\
\text { constant pressure } \\
\left(\mathrm{NCV} \mathrm{p}_{\mathrm{p}, \mathrm{d}}\right)^{*}\end{array}$ & $\mathrm{MJ} / \mathrm{kg}$ & $17.3 \pm 0.4$ & $17.1 \pm 0.3$ & \\
\hline
\end{tabular}

*With $0 \%$ mass fraction of water.

The system boundaries define which processes are included in the analysis, namely: the production of fertilizers and their subsequent transport to the field; the production of pesticides and the production of herbicides, including also their transport to the field; the production of electricity to be used for watering; the use of machinery, implying diesel production; and the field emissions from the input application. Additionally, since the carbon fixation of perennial crops is one of their major strengths compared to annual crops, the carbon sequestration in soil was taken into account.

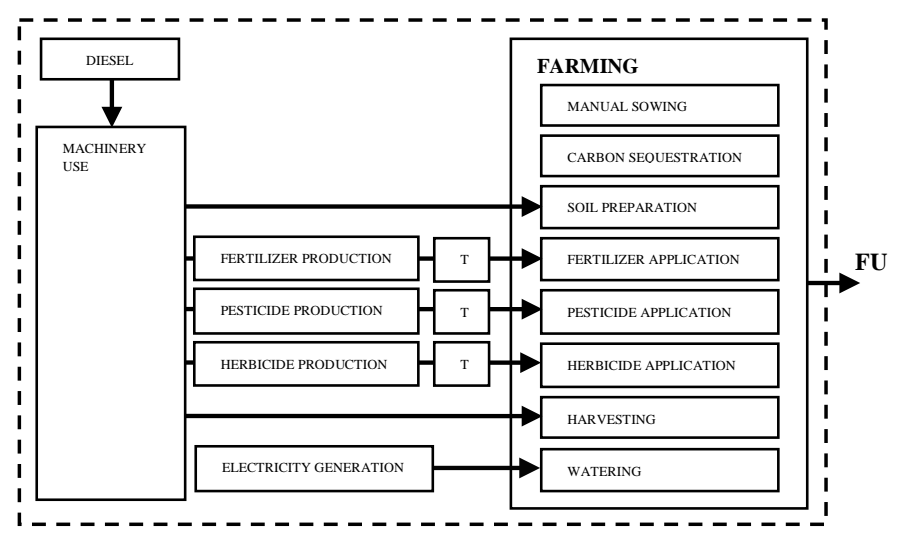

Figure 2. Substages included in the system under study for the cradle-to-farm gate LCA.

The production of capital goods was not included since, according to Frischknecht et al. [46], its contribution to most of the impact categories is not significant in agricultural LCAs, with the exception of the cumulative energy demand, not analysed in this case. Furthermore, it must be noted that, although the use of machinery is seasonal, it was 
rented; this implies a more intense use than if it belonged only to one farmer. Indeed, the study of Sastre et al. [47] demonstrates that the amortization of agricultural machinery plays a minor role in the life cycle GHG emissions of Spanish biomass. System boundaries are shown in Figure 2.

\subsection{System description}

Switchgrass cultivation was carried out in two experimental plots in the mentioned locations, providing primary data for the life cycle inventory (Tables 4 and 5). Each plot was divided in 12 subplots of $600 \mathrm{~m}^{2}$ for a randomized complete block design with three replications, corresponding to the study from Maletta et al. [48]. For the LCA, the cultivar "Alamo" was chosen since it was proved to be the best adapted to Southern European countries, also able to deliver higher yields, around $20 \mathrm{t} \mathrm{ha}^{-1}$ as reported by Heaton et al. [6].

Table 4. Experimental data of field operations for switchgrass production in Moncofar.

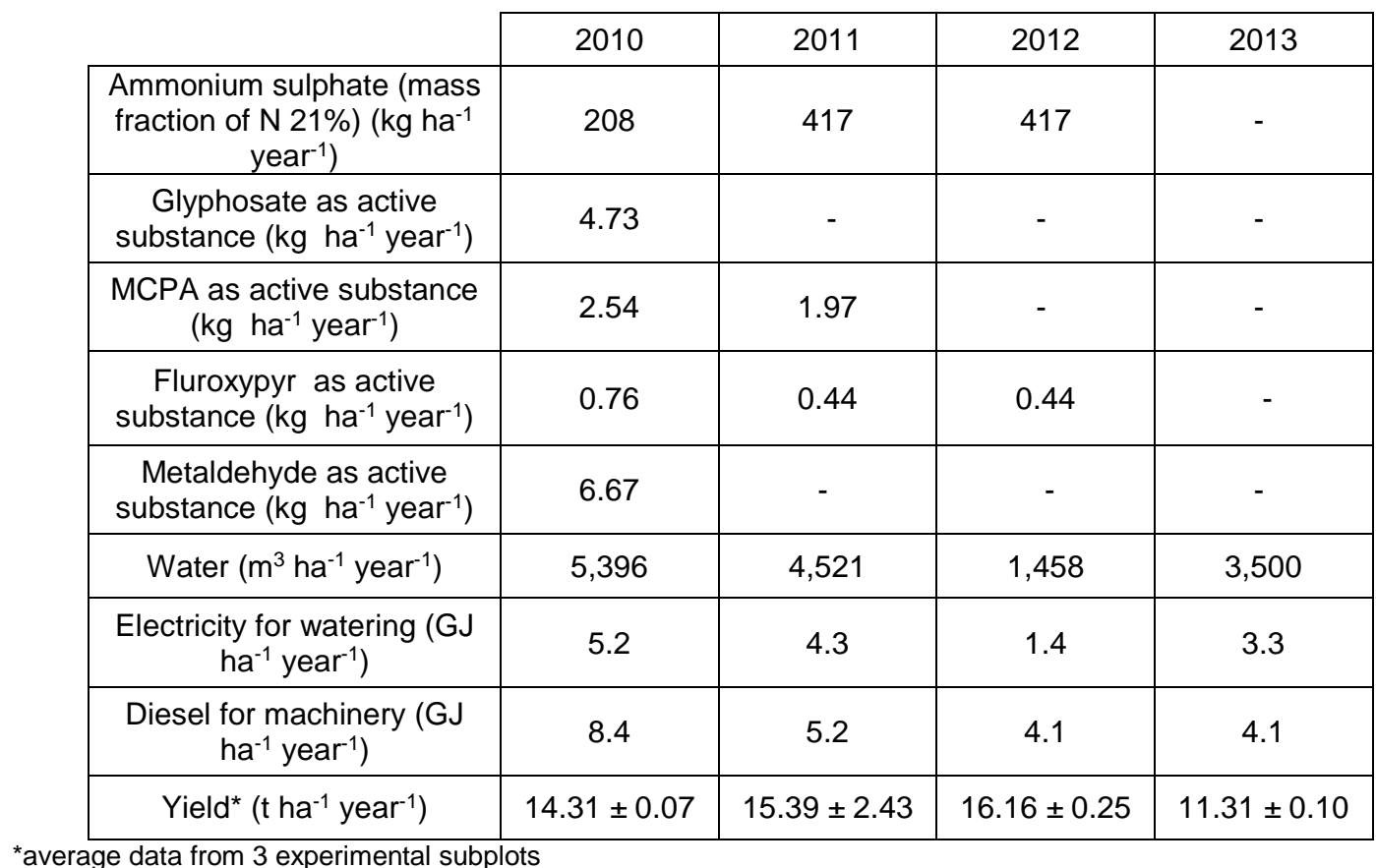

Soil preparation was carried out during the first year, prior the crop establishment, by using a subsoiler attached to a tractor and a rototiller powered by a tractor. Sheep manure was applied in Orihuela with a drawn dry spreader operated by a tractor. Manual seeding was carried out in the second half of April 2010 in the two locations, with a density of $20 \mathrm{~kg} \mathrm{ha}^{-1}$. The space between crop rows was $20 \mathrm{~cm}$ and the seeding depth around $0.25-0.50 \mathrm{~cm}$. Then, ammonium sulphate was manually applied in Moncofar, while a fertirrigation system with ammonium nitrate was established in Orihuela. In the following years, the crop regrew in March and harvesting took place once a year by means of a rotary cutter (Krone TM 2-165 D1) powered by a tractor (John Deere 2800); specifically, between the end of September and mid-November in Moncofar, and between the end of October and mid-December in Orihuela. The 1-cut annual system was chosen because it was proved to deliver reasonably high yields 
across Spain (from 10 to $40 \mathrm{t} \mathrm{ha}^{-1}$ ) [39]. Once the mowed material was air dried, it was baled with a squared baler.

Table 5. Experimental data of field operations for switchgrass production in Orihuela.

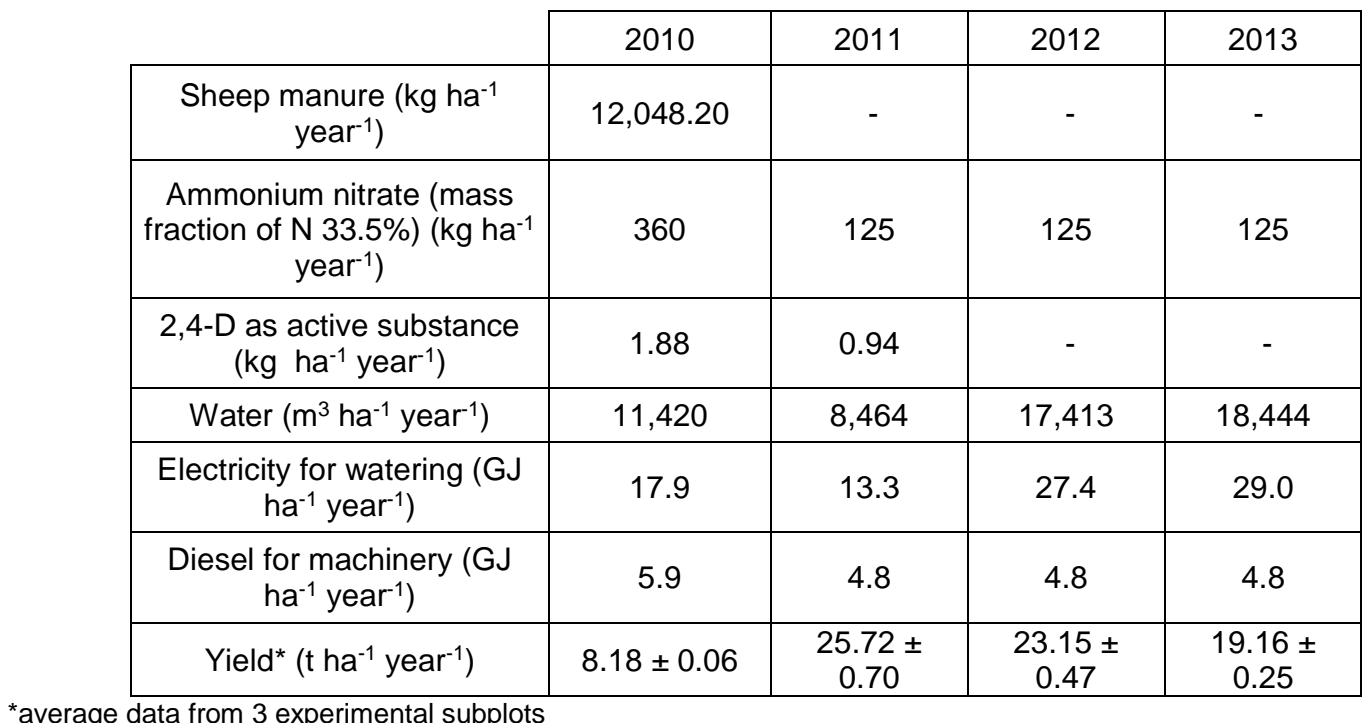

The yield was measured by taking samples right before harvest by cutting all the aboveground biomass in $1 \mathrm{~m}^{2}$ of soil to a stubble length of 4-10 cm. Cutting and sampling was performed manually by means of pruning shears to avoid contamination with soil particles. Three samples were randomly collected from each three replicated subplots. Each sample was weighed at the moment of harvest and the harvested material was subsequently introduced in a plastic bag and immediately sent to the laboratory, where samples were forced air-dried for $48 \mathrm{~h}$ at $40^{\circ} \mathrm{C}$. This allowed for dry matter yields to be estimated.

Technicians considered the type of soil when establishing the fertilization doses (see Table 2). Soils are loam-clay-sand in Orihuela and sandy-loam in Moncofar. Fertirrigation with ammonium nitrate was chosen in Orihuela for the whole period. In Moncofar, ammonium sulphate was again manually applied during the following two years and no fertilizer was used in the last year because technicians wanted to analyze the residual effect of $\mathrm{N}$ on the last year yield, considering that part of the ammonium sulphate used is in slow-release form. It must be pointed out that sheep manure was used in Orihuela before sowing due to the higher percentage of sand; this ensures a slow release throughout the cropping cycle, besides quick-release $\mathrm{N}$ is easily washed out of the root zone in this kind of soils.

For the purposes of weed control, herbicide application rates were conditional on the emergence of weeds in each location, which depend, in turn, on the bank of weed seeds in each subplot. As a result, treatments differed in the two locations: while 2,4-D was sprayed in Orihuela with a boom sprayer, a treatment with glyphosate was carried out before sowing in Moncofar. In this location, subsequent treatments in the following two years consisted of application of MCPA and fluroxypyr with a knapsack sprayer. Metaldehyde treatments against snails were also carried out in Moncofar in the first year. 
As for irrigation practices, the water came from a well in the two locations but strategies differed substantially due to the soil type, which determines its water holding capacity. Technicians opted for a deficit irrigation system (flood irrigation) in Moncofar, while much greater amount of irrigation water was applied in Orihuela due to the sandy soil, but using a drip irrigation system in order to reduce deep percolation losses. It must be pointed out that the differences in field operations mainly arise from the edaphoclimatic characteristics but also from the fact that previous experiences on this crop are scarce in Spain. Thus, technicians had to take crop management decisions based on their practice in other crops of the area.

\subsection{Inventory analysis}

In this phase of the LCA, all the environmentally relevant data on the stages previously described were gathered and expressed with respect to the FU. The main data sources are detailed in the following paragraphs.

Input manufacturing. Data on fertilizer and pesticide manufacturing came from the database Ecoinvent 3 [49], except for fluroxypyr, for which the method proposed by Audsley et al. [50] was followed. The emissions originated during manure maturation and storage were excluded because they were allocated to the manure producer, same as Nemecek and Kägi did [51]. The distance between the storehouse of the inputs and the farms was assumed to be $15 \mathrm{~km}$.

Energy consumption for watering. The power needed for watering was computed according to eq. 1.

$E=1.3[P \vee \rho g]$

Where $\mathrm{E}$ is the electricity, $\mathrm{P}$ is the pressure needed to pump the water up including the pressure in the watering heads, $V$ is the annual volume of water, $\rho$ is the water density and $\mathrm{g}$ is the gravity acceleration. A $30 \%$ increase is applied to consider the electric yield of the pump and water losses. The depth of the well is $75.0 \mathrm{~m}$ for the plot in Moncofar and $123.6 \mathrm{~m}$ for that in Orihuela. A pressure of $30 \mathrm{~m}$ of water column in the irrigation head was considered for drip irrigation. As a result, while $1.57 \mathrm{MJ} \mathrm{m}^{-3}$ of water were needed in Orihuela, only $0.96 \mathrm{MJ} \mathrm{m}^{-3}$ were employed in Moncofar. The Spanish electricity mix was the one in Ecoinvent 3 [49].

Table 6. Main technical characteristics of the tractors and implements employed for the field operations in Moncofar.

\begin{tabular}{|c|c|c|c|c|c|}
\cline { 2 - 6 } \multicolumn{1}{c|}{} & \multicolumn{2}{c|}{ Working time $\left(\mathrm{h} \mathrm{ha}^{-1}\right)$} & $\begin{array}{c}\text { Fuel } \\
\text { consumption } \\
\left(\mathrm{dm}^{3} \mathrm{~h}^{-1}\right)\end{array}$ & Power (kW) & $\begin{array}{c}\text { Implement } \\
\text { weight }(\mathrm{kg})\end{array}$ \\
\cline { 2 - 6 } & 2010 & $2011-2012-2013$ & 3.51 & 117.7 & 375 \\
\hline $\begin{array}{c}\text { Soil preparation: } \\
\text { subsoiler }\end{array}$ & 1.85 & - & 0.7 & 117.7 & 1,005 \\
\hline $\begin{array}{c}\text { Soil preparation: } \\
\text { rototiller }\end{array}$ & 9.26 & - & 0.68 & 73.55 & 410 \\
\hline Harvester & 7.41 & 7.41 & 0.54 & 73.55 & 1,540 \\
\hline Baler & 9.26 & 9.26 & \multicolumn{2}{c}{}
\end{tabular}


Emissions from machinery use. These emissions were calculated from to the power of the specific tractors employed in each location. To this aim, the process for tractor operation in GaBi 6.0 [52] was adapted by taking the specific number of hours devoted to the agricultural works into account. The overall diesel consumption was then obtained from the hourly diesel consumption for each work. The main features of the machinery and implements considered are summarized in Tables 6 and 7.

Table 7. Main technical characteristics of the tractors and implements employed for the field operations in Orihuela.

\begin{tabular}{|c|c|c|c|c|c|c|}
\hline & \multicolumn{3}{|c|}{ Working time $\left(\mathrm{h} \mathrm{ha}^{-1}\right)$} & \multirow{2}{*}{$\begin{array}{c}\text { Fuel } \\
\text { consumption } \\
\left(\mathrm{dm}^{3} \mathrm{~h}^{-1}\right)\end{array}$} & \multirow{2}{*}{ Power (kW) } & \multirow{2}{*}{$\begin{array}{l}\text { Implement } \\
\text { weight }(\mathrm{kg})\end{array}$} \\
\hline & 2010 & 2011 & $2012-2013$ & & & \\
\hline $\begin{array}{l}\text { Manure } \\
\text { application }\end{array}$ & 0.48 & - & - & 13.46 & 73.55 & 3,000 \\
\hline $\begin{array}{l}\text { Soil preparation: } \\
\text { subsoiler }\end{array}$ & 1.81 & - & - & 3.59 & 117.7 & 375 \\
\hline $\begin{array}{l}\text { Soil preparation: } \\
\text { rototiller }\end{array}$ & 6.88 & - & - & 0.94 & 117.7 & 1,005 \\
\hline $\begin{array}{l}\text { Herbicide } \\
\text { application }\end{array}$ & 4.35 & 2.17 & - & 1.5 & 73.55 & 665 \\
\hline Harvester & 7.41 & 7.41 & 7.41 & 0.68 & 73.55 & 4,173 \\
\hline Baler & 9.26 & 9.26 & 9.26 & 0.54 & 73.55 & 1,540 \\
\hline
\end{tabular}

Fate of pesticides. To calculate the fate of pesticides, the method proposed by Berthoud et al. [53] was followed. The vapour pressure of the active ingredient was taken from the Pesticide footprint database [54].

Emissions from fertilizers use. The application of fertilizers in the field generates emissions of $\mathrm{NH}_{3}, \mathrm{~N}_{2} \mathrm{O}, \mathrm{NO}_{3}$ and $\mathrm{P}$. With respect to $\mathrm{NH}_{3}$ volatilization from manure and chemical fertilizers, emission factors from EMEP/EEA [55] were used. Direct and indirect $\mathrm{N}_{2} \mathrm{O}$ emissions from denitrification were calculated according to IPCC [56]. $\mathrm{NO}_{3}{ }^{-}$leaching were calculated based on Nemecek et al. [57]. These authors employ the SQCB-NO3 model described by Faist-Emmenegger [58], which is, in turn, an adaptation of a formula developed by de Willigen [59]. For estimating $P$ leaching and run-off, the procedure proposed by Nemecek et al. [57] was followed.

Carbon sequestration. Since the carbon content in soil at the end of the period of analysis was not measured, the net carbon sequestration was taken from literature. Specifically, the average value of $3.75 \cdot 10^{-2} \mathrm{Mg} \mathrm{t}^{-1}$ year-1 of $\mathrm{C}$ [24] was considered. Although the effective soil $\mathrm{C}$ sequestration rate greatly depends on the different conditions of soil, crop, and climate, Cherubini and Jungmeier [24] took the variability in estimations into account, based on an extensive literature review. Specifically, they considered a range of 0.2-1.1 $\mathrm{Mg} \mathrm{ha}^{-1}$ year ${ }^{-1}$. Besides, authors assumed that switchgrass was grown on poor quality soil, which is consistent with our case study. For the year of the crop establishment, the lowest value of $1.25 \cdot 10^{-2} \mathrm{Mg} \mathrm{t}^{-1}$ year $^{-1}$ of $\mathrm{C}$ was considered, coinciding with the most unproductive crop stage, according to Lerkkasemsan and Achenie [60]. 
Land use change emissions. Switchgrass was planted on arable land, which was taken as the reference land use. Specifically, the previous crop was artichoke in Orihuela, while the land had been idle for three years in Moncofar. Direct $\mathrm{CO}_{2}$ emissions from carbon stock changes prior to soil preparation were neglected according to IPCC [56], under the Tier 1 approach. As for ILUC, the same assumption as that of Sastre et al. [47] was made: in Spain, switchgrass cultivation for electricity production is very likely to occur in marginal land and expected ILUC emissions are of minor importance.

\subsection{Impact assessment}

The ReCiPe method [61] was chosen for the life cycle impact assessment. The following midpoint impact categories were analyzed, consistent with those identified as critical by [21]: climate change ( $\mathrm{CC}, 100$ years; $\mathrm{kg}$ of $\mathrm{CO}_{2}$-eq.), metal depletion (MD, $\mathrm{kg}$ of Fe-eq.), fossil depletion (FD, kg of oil-eq.), terrestrial acidification (TA, $\mathrm{kg}$ of $\mathrm{SO}_{2}$ eq.), freshwater eutrophication (FE, $\mathrm{kg}$ of P-eq.), ozone depletion (OD, kg of CFC-11eq.), and photochemical oxidant formation (POF, kg of NMVOC-eq.). On the other hand, ecotoxicity (ET) and human toxicity (HT) were calculated following the USEtox method [62], expressed in comparative toxic units, CTUeco and CTUh, respectively.

Additionally, the impacts of freshwater consumption were assessed by taking both green and blue water into account. Blue water denotes consumption of any surface and groundwater and, in the case of agricultural production particularly, irrigation water. Green water, in contrast, is precipitation and soil moisture consumed on-site by vegetation. To assess the impact of blue water consumption or freshwater ecosystem impact (FEl, $\mathrm{m}^{3}$ ecosystem-eq. water), the method proposed by Hospido et al. [63] was followed, based in turn on the midpoint indicator defined by Milà i Canals et al. [64]. The impact derived from green water consumption (green water impact, GWI, $\mathrm{m}^{3}$ ecosystem-eq. water) was estimated according to Núñez et al. [65], under the productive scope. Both methods are detailed in the Electronic Supplementary Material (ESM).

\section{Results}

Impact results for each year of the production cycle in the two locations are presented in Figure 3; the contribution of each substage is equally shown. In Orihuela, the first year of cultivation clearly represents the highest values for all the impact categories. This is mainly due to the high dose of fertilizers, manure and water used, as combined with lower yields; the mean yield was then $43 \%$ lower than that in Moncofar. Impact values in Orihuela show an increasing trend for the period 2011-2013, in tune with the declining yields; the toxicity-related categories are an exception to this, since no pesticides were applied in the last two years. In Moncofar, the highest fertilizer doses are reported for the second and third years. The second one translates into greater impacts for those categories to which the fertilizer production makes a substantial contribution. This is the result of the lower yield, relative to the third year, as combined with the higher input intensity (i.e. fertilizers and water). Note that the yields obtained after the first year are between $43 \%$ to $69 \%$ higher in Orihuela than in Moncofar, which is detrimental for the environmental profile of the switchgrass produced in the latter location. 

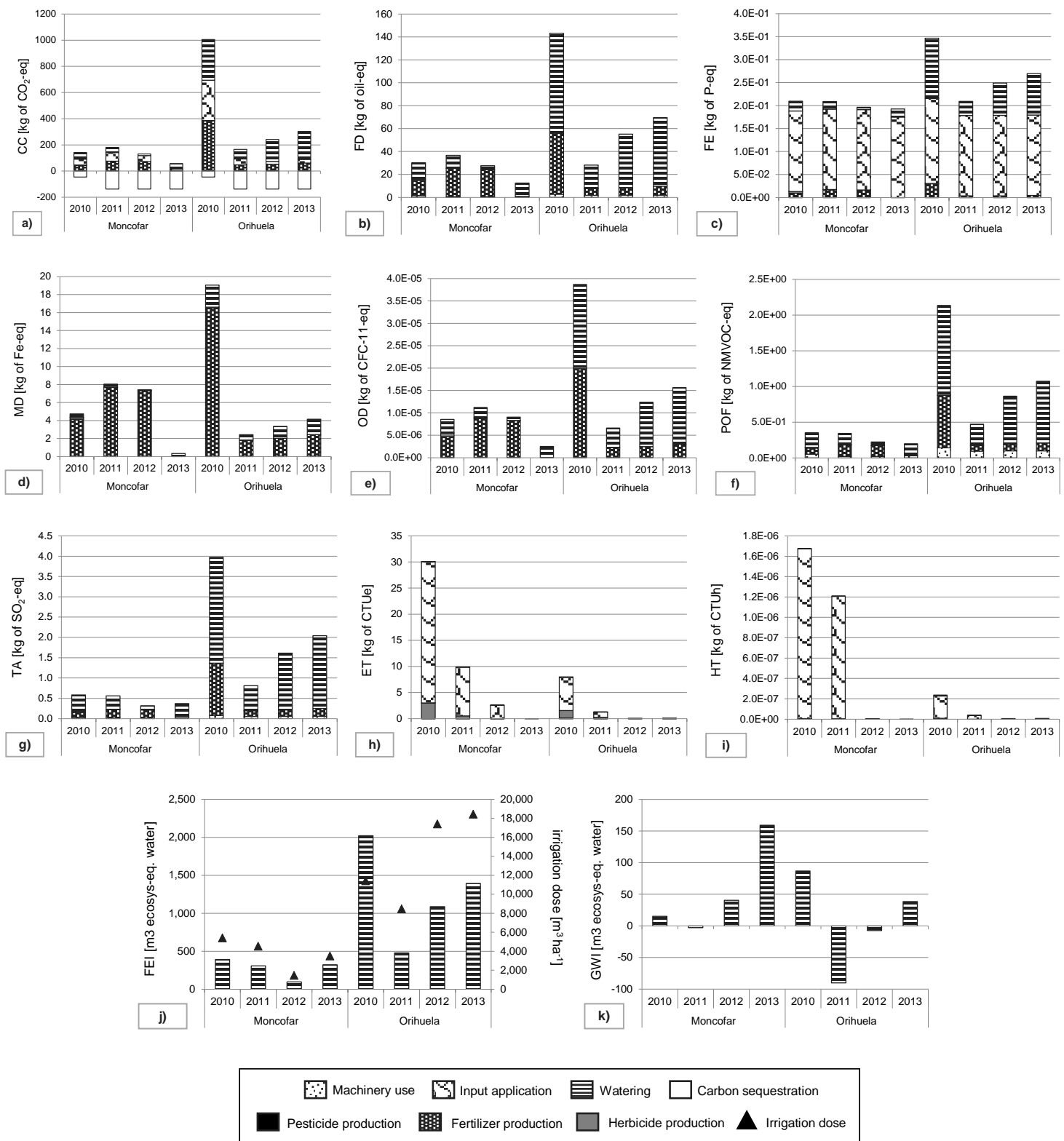

Figure 3. Impact results for the crop's entire production cycle in the two locations (per $1 \mathrm{t}$ of switchgrass, dry biomass). a) Climate change (CC), b) fossil depletion (FD), c) freshwater eutrophication (FE), d) metal depletion (MD), e) ozone depletion (OD), f) photochemical oxidant formation (POF), g) terrestrial acidification (TA), h) ecotoxicity

$(E T)$, i) human toxicity $(H T)$, j) freshwater ecosystem impact (FEI), k) green water impact (GWI). The dot plot in j) corresponds to the irrigation dose $\left(\mathrm{m}^{3} \mathrm{ha}^{-1}\right)$, in the secondary axis. 
On a year-to-year comparison, impacts are usually greater in Orihuela mainly due to differences in watering. There are some exceptions though, besides GWI, which will be further described below, in the context of the methodology applied. Specifically, for 2010, ET and HT are 73\% and 86\% lower in Orihuela relative to Moncofar, respectively (Figures 3h and 3i). In 2011, all the impacts are lower in Orihuela except for FE, POF and TA (Figures $3 \mathrm{c}, 3 \mathrm{f}$ and $3 \mathrm{~g}$ ). This is essentially due to the high yield obtained in the second year for this location. On the contrary, for the rest of the crop cycle, impact results are better in Moncofar, except for MD and ET in 2012; in this case switchgrass cultivation in Orihuela generates 55\% and 97\% lower impacts, respectively (Figures $3 d$ and $3 \mathrm{~h}$ ). In order to discuss these differences further, the relative contribution of each life cycle stage to the overall impact is examined.

As could be expected, the input application is the substage contributing the most to FE, ET and HT (Figures 3c, 3h and 3i); specifically, it accounts for more than $83.5 \%$ of the aforementioned impacts in Moncofar and between $53.5 \%$ and $92.3 \%$ of these in the case of Orihuela. As for FE, this is due to direct $\mathrm{P}$ emissions from the use of fertilizers (as will be discussed in section 4), while ET and HT are mainly generated by emissions from pesticide and herbicide application. The cultivation of switchgrass in Moncofar is particularly intensive in the use of such chemical compounds, especially in 2010. This is due to the high presence of weeds before the crop establishment, since the land had been idle for a long time. Hence, the herbicide production makes a notable contribution to ET in the first two years of the crop cycle in this location: around $9.8 \%$ in 2010 and $4.8 \%$ in 2011 . The herbicide production is responsible for $9.7 \%$ of the OD in 2010 as well. In the case of Orihuela, this substage accounts for around $17.5 \%$ of ET in 2010 and 2011, since the overall impact is much lower relative to that in Moncofar.

The fertilizer production makes a significant contribution to the following impact categories in both Moncofar and Orihuela: CC, FD, MD, OD, POF, and TA (Figures 3a, $3 b, 3 d, 3 e, 3 f$, and $3 g$ ). Specifically, this substage represents between $12.2 \%$ and $35.8 \%$ of the overall CC in the two locations; it must be noted that no fertilizers were applied in 2013 in Moncofar. The greatest impact share of the fertilizer production substage is observed for MD; it accounts for more than $87.1 \%$ of the impact in Moncofar for the period 2010-2012, and for between $59.0 \%$ and $86.5 \%$ of the impact in Orihuela. The contribution of the fertilizer production to FD and OD is also substantial in the two locations (between $44.0 \%$ and $91.8 \%$ in Moncofar; between $11.4 \%$ and $51.3 \%$ in Orihuela). In general, these proportions are lower in Orihuela due to the influence of watering, which is definitely a decisive substage in this location. This is the result of the larger irrigation needs as combined with the greater depth of the well, which entails larger electricity consumption to pump the water. As a result, watering is the most influential substage for this location in the impact categories FD, OD, POF and TA, accounting for up to $88.0 \%$ of the impacts. Impacts from machinery use are negligible since most of the agricultural works are not mechanized (except for harvesting and baling). However, the contribution of this substage to POF is remarkable, mainly in the first year, due to the soil preparation techniques.

The carbon footprint is largely influenced by the carbon uptake of the crop. Under the approach selected, it takes a constant value (in terms of $\mathrm{Mg}$ of $\mathrm{CO}_{2}$ per tonne of switchgrass) throughout the crop cycle in the two locations, except for the first year. As a result, the carbon sequestration substage makes the greatest contribution to $\mathrm{CC}$ for the period 2011-2013 in Moncofar (between 43.1\% and $70.8 \%$ of the overall impact) 
and in Orihuela for 2011 (45.3\%). For the rest of the years, the carbon sequestration contribution is only smaller than that of watering.

As for water impacts, the potential damage of blue water consumption is between 1.6 and 11.6 times higher in Orihuela than that in Moncofar. This is due not only to the high irrigation water consumption (secondary axis of Figure 3j), but also to the high characterization factor of the Segura basin (1.445 vs. $1.035 \mathrm{~m}^{3}$ ecosystem-eq. water per $\mathrm{m}^{3}$ of irrigation water, as described in the ESM). The latter indicates that the water withdrawals in this watershed exceed availability to a greater extent than in the Jucar one. The highest FEI in Orihuela is obtained for 2010, given the low biomass yield, although the blue water consumption per ha is higher in 2013 (see Figure 3j). In Moncofar, 2010 is the year for which both blue water consumption $\left(\mathrm{m}^{3} \mathrm{ha}^{-1}\right)$ and FEI $\left(\mathrm{m}^{3}\right.$ ecosystem eq. per tonne of dry matter) are the highest. The second largest value of FEl is calculated for 2013 , influenced by the yield decrease. The largest differences between the two locations are calculated for 2012, in which the irrigation dose is around 12 times larger in Orihuela.

With regard to GWI (Figure 3k), values are higher in Moncofar except for the first year. This arises from the difference in green water consumption between switchgrass and the reference crop (citrus), represented by the dGW parameter (for further information, see section $S 1$ in the ESM). A positive value for dGW means that switchgrass consumes more green water ( $\mathrm{m}^{3}$ ecosystem eq. per tonne) than the reference crop and the other way round. In 2010 , the monthly evapotranspiration $\left(E T_{c}\right)$ of switchgrass was higher in Moncofar, since the plants were slightly taller in the early stages (probably due to the less extreme conditions as compared to Orihuela). On the contrary, the $\mathrm{ET}_{\mathrm{c}}$ of the citrus was higher in Orihuela, due to the higher average temperatures. Note that citrus consumes green water in larger amounts than switchgrass does in terms of litres per ha, with greater differences in Orihuela. However, when taking the yields into account, the biomass yield in Orihuela was much lower than that in Moncofar, while the citrus yields were very similar according to MAGRAMA [66]. This is why, under a productive scope, the GWI is greater in Orihuela for the first year. In 2011, the $E T_{c}$ of switchgrass was again higher in Moncofar than in Orihuela. Since the $\mathrm{ET}_{\mathrm{c}}$ was higher for citrus than for switchgrass, the dGW parameter is negative in the two locations and lower in Orihuela due to the aridity conditions.

In the medium-term and final stages of the crop, the plant has reached the maximum height. As a consequence of the more extreme conditions, the switchgrass' $\mathrm{ET}_{\mathrm{c}}$ in 2012 and 2013 was higher in Orihuela, as happened with the citrus in the previous years. However, according to the GWI calculation method (see the ESM), the green water consumption of switchgrass is given by $\mathrm{Pr}^{\prime}$ in most of the months, being especially low in Orihuela. This means that there is less green water available in Orihuela due to the higher average temperatures and less rainfall. When compared to the reference crop, dGW is larger in Moncofar, also because the yields are lower for both switchgrass and citrus. 


\section{Discussion}

\subsection{Factors influencing impact variability}

Results from this study confirm that outcomes from switchgrass LCAs may radically change depending on the growth phase of the plant, local conditions, and agricultural practices. These two case studies represent two different crop management plans for the switchgrass production in two locations of Comunidad Valenciana that correspond to two different watersheds. Agricultural practices can be very diverse, even in the same region, since variables such as soil type, are more likely to conform to ecological boundaries such as watersheds [25]. Boone et al. [36] emphasise the need for specific data on soil type, as fertiliser use is determined by the location, while fertiliser emissions are influenced by local edaphoclimatic conditions. Furthermore, in perennial crops, not accounting for unproductive phases may lead to misleading results, as happens in most of the LCAs, which focus on a full production year $[28,38]$. Once established, switchgrass may take 3 years to come to its full production potential, reaching an average annual yield of $16 \mathrm{t} \mathrm{ha}^{-1}$ in European settings [22]. In this case, the environmental performance of switchgrass has been analysed throughout a 4-year cycle, also capturing yield variability by means of a mass-based FU. The main factors contributing to impact variability are further discussed below:

Temporal variability: The third year, that is 2012 , can be taken as the full production stage in both Moncofar and Orihuela. Nevertheless, the yield obtained in Orihuela for that very year is much higher than other values in the literature for both North American and Mediterranean conditions $[6,11,22]$. This is the result of more intensive agricultural practices, especially for the crop establishment; indeed, in Orihuela, the highest yield is obtained right the second year $\left(26 \mathrm{t} \mathrm{ha}^{-1}\right)$. Although the study of Alexopoulou et al. [11] is based in Southern Europe, authors assessed biomass production by using low-input techniques. However, crop establishment usually implies intensive soil preparation practices and pre-seeding fertilization, especially when marginal land is employed $[17,24]$.

Variability of the production site/spatial variability: As has been said, soils are basic in the two locations $(\mathrm{pH}>7.8)$. Despite the fact that strongly basic soils might have limited availability of mineral elements [9], conservative criteria were followed when establishing fertilization plans, in accordance with Berg [67]. The highest values correspond to the first year in Orihuela $\left(245.0 \mathrm{~kg} \mathrm{~N} \mathrm{ha}^{-1}\right)$, where soils are sandy (Table 2), and to the second and third years in Moncofar (87.6 kg N ha-1). Boone et al. [36] also report larger resource consumption in sandy soils. Sheep manure was chosen in Orihuela since it ensures a slow release throughout the cropping cycle, besides quickrelease nitrogen is easily washed out of the root zone in sandy soils. Although using manure has significant $\mathrm{CC}$ implications due to $\mathrm{N}_{2} \mathrm{O}$ emissions, it reduces emissions from the production of fertilizers; these make a major contribution to CC in 2010 in Orihuela (Figure 3a). Thus, partially relying on organic fertilization may be a good alternative for the switchgrass establishment in sandy soils.

On the other hand, in the Mediterranean region, water availability may be strongly limited, depending on local or regional circumstances [30]. In this study, CFs for water use impacts were calculated at the watershed level. This spatial differentiation is important in a region where switchgrass is necessarily produced under irrigation. Note 
that water availability can become a crucial consideration for the establishment of bioenergy crops in the short run [68].

Variability in management practices: As has been seen, farmers' personal choices play obviously a key role in the environmental performance. It must be borne in mind that a specific agronomic decision (e.g. increase fertilization rates) is very likely to affect the system response in the subsequent years, making the difference in short crop cycles. For instance, weedy species may increase with $\mathrm{N}$ fertilization [44]. This reinforces the need for addressing temporal variability, which influences both agricultural practices and yields at the same time, generating synergies in the LCA results. For perennial long-cycle crops, it is recommend collecting annual average inflows and outflows over a period of at least four years [37]. The present study estimates the impacts for a 4year crop cycle, under a chronological approach [28]. However, considering longer lifetimes (>10 years) is advisable, in order to investigate long-term productivity and address key site factors, such as $[11,22,23,25]$ did.

Unfortunately, the interpretation of results when more than one year is considered can increase the difficulty linked to multiple outcomes interpretation. A single score can greatly facilitate the dissemination of results. In perennial tree crops, the impacts of the crop establishment can be distributed over the life span of the plantation $[29,38,44]$. In this way, the longer the life spans, the lower the contribution of the soil preparation, etc. However, in our case study, this establishment share would be significant, especially in Orihuela, given the magnitude of the impacts in the early stages and the length of the switchgrass cycle considered. Hence, using the average of the impact for all the years of the cycle can be a good approach for a simplified comparative assessment. Average results are shown in Table 8 ; it can be seen that the difference Orihuela minus Moncofar is positive for all the impact categories except GWI.

Table 8. Average impact results (per ton of dry biomass) for the 4 years of the switchgrass cycle in the two locations.

\begin{tabular}{|l|c|c|}
\cline { 2 - 3 } \multicolumn{1}{l|}{} & Moncofar & Orihuela \\
\hline Climate change (kg of $\mathrm{CO}_{2}$-eq) & 13.05 & 314.22 \\
\hline Fossil depletion (kg of oil-eq.) & 26.73 & 74.07 \\
\hline Freshwater eutrophication (kg of P-eq.) & 0.20 & 0.27 \\
\hline Metal depletion (kg of Fe-eq.) & 5.13 & 7.25 \\
\hline Ozone depletion (kg of CFC-11-eq.) & $7.81 \mathrm{E}-06$ & $1.83 \mathrm{E}-05$ \\
\hline Photochemical oxidant formation (kg of & 0.28 & 1.13 \\
\hline NMVOC-eq.) & & 2.11 \\
\hline Terrestrial acidification (kg of SO ${ }_{2}$-eq.) & 0.45 & 2.37 \\
\hline USEtox, Ecotoxicity (CTUe) & 10.63 & $7.20 \cdot 10^{-8}$ \\
\hline USEtox, Human toxicity (CTUh) & $7.22 \cdot 10^{-7}$ & 1243.3 \\
\hline FEl (m ${ }^{3}$ ecosystem-eq.) & 277.0 & 6.9 \\
\hline GWI (m ${ }^{3}$ ecosystem-eq.) & 53.0 & \\
\hline
\end{tabular}




\subsection{Viability of switchgrass in the studied areas}

Specifically, Directive 2015/1513, amending Directive 2009/28/EC -commonly known as Renewable Energy Directive (RED)-, requires that $20 \%$ of the gross final energy consumed in the European Union (EU) comes from renewable sources, in order to meet the EU's climate change and energy sustainability goals. The new RED, currently being prepared by the European Commission, is expected to reinforce this commitment for the period 2020-2030.

Switchgrass produced in these locations would be ultimately diverted to electricity production by combustion and hence must fulfil the RED's sustainability criteria, mirrored in [69]. Specifically, electricity production from switchgrass should generate GHG savings of at least $60 \%$ in new installations from 1 January 2018, as compared to a fossil reference. In order to calculate life cycle emissions, the system boundaries should be extended so that conversion of the biomass fuel to electricity is included. To this aim, GHG emissions from the biomass transport and subsequent combustion were taken from Sastre et al. [47,70], for being based on Spanish conditions. Authors considered a 25 MWe combustion plant, with a conversion efficiency of $29.5 \%$. The net calorific value at constant pressure $\left(\mathrm{NCV}_{\mathrm{p}, \mathrm{d}}\right)$ of the switchgrass was taken from Table 3. GHG savings were calculated relative to a fossil fuel comparator [69], without considering the carbon uptake, and are shown in Table 9.

Table 9. GHG savings (\%) generated by electricity from switchgrass from the two locations, in an average Spanish combustion plant [47]. An emission intensity $198 \mathrm{~g}$ of $\mathrm{CO}_{2}$-eq. $\mathrm{MJ}^{-1}$ of electricity has been considered for the fossil fuel comparator [69].

\begin{tabular}{|c|c|c|c|c|}
\cline { 2 - 5 } \multicolumn{1}{c|}{} & 2010 & 2011 & 2012 & 2013 \\
\hline Moncofar & $84.0 \%$ & $80.0 \%$ & $85.2 \%$ & $92.7 \%$ \\
\hline Orihuela & $-6.0 \%$ & $81.3 \%$ & $73.5 \%$ & $67.0 \%$ \\
\hline
\end{tabular}

The 2018 GHG saving requirement is largely met if switchgrass from Moncofar was employed, regardless the year of the cycle in which the feedstock is produced. Electricity from switchgrass cultivated in Orihuela also meets the target except for the year of the crop establishment, for which the highest input intensity is reported. This implies that the feedstock obtained from this stage should be diverted to other uses, ideally able to generate revenues for the producer (e.g. forage production) apart from that of soil conservation. In any event, switchgrass from these two locations can certainly be a suitable alternative to produce electricity under the management practices proposed. The fact remains that further management optimization is always desirable for the purposes of sustainability, also taking the economic dimension of it into account.

Efforts should focus on genotype selection in order to increase yields, without increasing fertilizer doses [36]. However, innovation plant breeding would bring further impact variability to be assessed. It is equally important to optimize irrigation systems, given the influence of the water supply on the biomass yield variability throughout the production cycle [71]. In this sense, fertirrigation can help to ensure a regular supply of water, provided that the flow is conveniently adjusted. Such these decisions are crucial 
for consolidating the potential for perennial grasses to deliver greater GHG savings than annual crops; even than wastes such as wheat straw. According to Sastre et al. [47], the cultivation of winter cereals in Spain alone causes between 27 and $43 \mathrm{~g}$ of $\mathrm{CO}_{2}$-eq. $\mathrm{MJ}^{-1}$ of electricity, depending on the region; the agricultural production of wheat straw generates around $50 \mathrm{~g} \mathrm{MJ}^{-1}$ [70]. Based on our results, the cultivation of switchgrass in Moncofar generates between 11.5 and $36.7 \mathrm{~g}$ of $\mathrm{CO}_{2}$-eq. per $\mathrm{MJ}^{-1}$ of electricity, while it generates between 34.2 and $62.4 \mathrm{~g}$ of $\mathrm{CO}_{2}$-eq. per $\mathrm{MJ}^{-1}$ of electricity when it is produced in Orihuela (only for the "eligible" years). Emission factors allow for different feedstocks to be compared.

Similarly, the environmental performance of the electricity from switchgrass can be compared to wind generated electricity and to that from natural gas, as best-case and worst-case scenarios in Spain, respectively [70]. Besides CC, TA has also been considered for the analysis and emission factors for the reference processes have been taken from Ecoinvent 3 [49], as the electricity comparators. In this case, the results from Butnar et al. [72] have been used, in order to estimate overall life cycle emissions from switchgrass electricity production under Spanish conditions. Figure 4 shows the outcomes from the comparative analysis, based on CC and TA values for switchgrass cultivation in 2012 , as the year of full production.

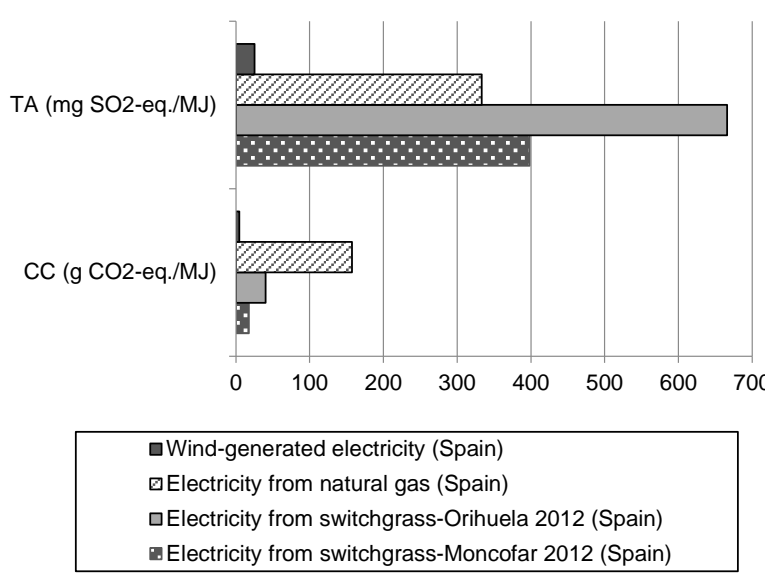

Figure 4. Climate change (CC) and terrestrial acidification (TA) emission factors, in terms of $\mathrm{g}$ of $\mathrm{CO}_{2}$-eq. $\mathrm{MJ}^{-1}$ and $\mathrm{mg}$ of $\mathrm{SO}_{2}$-eq. $\mathrm{MJ}^{-1}$, respectively, for four options for electricity production in Spain.

It can be seen that, in terms of $\mathrm{CC}$, the option with the lowest emission factor is windgenerated electricity, as could be expected. Bio-based electricity production generates a $74.5 \%$ and $88.9 \%$ reduction in the carbon footprint relative to electricity from natural gas when switchgrass from Orihuela and Moncofar is used, respectively. The $\mathrm{CO}_{2}$ emissions factors are, in this case, 40.1 and $17.4 \mathrm{~g}$ of $\mathrm{CO}_{2}$-eq. per $\mathrm{MJ}^{-1}$, respectively; these values are consistent with those previously obtained based on [70]. When it comes to TA, though, the environmental performance of electricity from switchgrass is even worse than that of the one produced from natural gas. Specifically, $\mathrm{SO}_{2}$ emissions factors are $99.8 \%$ and $19.4 \%$ higher than those of electricity from natural gas. This demonstrates that other impacts besides $\mathrm{CC}$ should be addressed when evaluating the 
sustainability of irrigated bioenergy crops. Processes such as watering and fertilizer production can be decisive for impacts typically associated to agricultural production, such as acidification.

When compared to LCA results for other geographic locations, switchgrass cultivation under Mediterranean conditions may generate greater impacts. Smeets et al. [22] obtained emission factors around $6.4-7.5 \mathrm{~g}$ of $\mathrm{CO}_{2}$-eq. per $\mathrm{MJ}^{-1}$ for the cultivation stage alone, while these are calculated at 26.4 and $49.6 \mathrm{~g}$ of $\mathrm{CO}_{2}$-eq. per $\mathrm{MJ}^{-1}$ for Moncofar and Orihuela, respectively, in 2012. As for TA, the values reported by Sinistore et al. [25] are around $0.1 \mathrm{~g}$ of $\mathrm{SO}_{2}$-eq. per $\mathrm{MJ}^{-1}$, while these are in the range $6.4 \cdot 10^{-2}-1.17 \cdot 10^{-}$ ${ }^{1} \mathrm{~g}$ of $\mathrm{SO}_{2}$-eq. per $\mathrm{MJ}^{-1}$ for Moncofar and 0.17-0.82 $\mathrm{g}$ of $\mathrm{SO}_{2}$-eq. per $\mathrm{MJ}^{-1}$ for Orihuela. These differences arise from the variability in management techniques. Although $\mathrm{N}$ fertilization rates in literature $\left(75-125 \mathrm{~kg} \mathrm{ha}^{-1}\right.$ of $\left.\mathrm{N}\right)[22,73]$ are similar to those applied in Moncofar, no irrigation water was used in those two case studies. Switchgrass production in Orihuela implies a much more intensive agriculture in the use of both fertilizers and water.

Furthermore, there are also differences in the way that land conversion is addressed in the literature. As has been said, Sastre et al. [47] considered marginal land as the reference land use scenario in Spain while Sinistore et al. [25] considered a conventional corn-soybean in the American Midwest. Not surprisingly, the net GHG saving is substantial if switchgrass is grown in former arable lands, although it is slightly negative to positive if switchgrass replaces permanent grassland [20]. Some authors also argue that the impact of switching green water from other uses should be better addressed as a land use change impact [74]. In this case, considering an areabased FU would be recommended, which captures multi-functionality of agricultural systems; this allows for several options of land uses and agricultural practices to be compared without the interference of yields. This is why, when comparing different soil types, the results obtained with a mass-based FU must be carefully interpreted.

Finally, switchgrass expansion can cause ILUC if it comes at the expense of arable crops, hence the importance of its adaptability to marginal lands. Nevertheless, most of the authors did not consider ILUC for being out of the scope and due to uncertainties in measurements [20,25]. On the contrary, Schmidt et al. [30] considered ILUC but not carbon sequestration because it is also subject to great uncertainties arising from variability in both soil and climate properties and agricultural practices as well. In this case study, carbon sequestration figures have been estimated from literature, where they are frequently expressed in terms of $\mathrm{kg} \mathrm{ha}^{-1}$ of $\mathrm{C}$. This entails a simplification of the real mechanisms underlying carbon fixation by photosynthesis. Better estimates of carbon sequestration in the two locations would increase results reliability, given the contribution of this substage to the carbon footprint (Figure 3a). These should be ideally obtained by performing soil tests before the implantation of the crop and after the last harvest, since carbon sequestration should be correlated to the crop's belowground biomass productivity [20], which in turn depends on the aboveground productivity, that is, yields. 


\section{Conclusions}

An LCA has been performed on switchgrass cultivation in two Mediterranean locations of Spain (Comunitat Valenciana), where there were no previous experiences on this crop. Results show that ad hoc decisions on the crop management are critical for the environmental performance. Those agricultural practices aimed at increasing biomass yields can indeed lead to increased impacts, as happens in the case of Orihuela. In this location, the year of the crop establishment generates the greatest impact values for all the analysed impact categories. However, the yields subsequently obtained contribute to the environmental footprint reduction in the rest of the crop cycle. Although impacts are contingent on the farmers' decisions in this regard, a mass-based FU is recommended to capture synergies from intensification. In this way, LCA can provide robust estimates on whether higher yields or less intensive practices are desirable from the environmental point of view.

Results prove that decreased GHG emissions may come at the cost of increasing other impacts such as those greatly influenced by the production of fertilizers and watering (e.g. MD, OD, TA, etc.). This is exactly the case for toxicity-related impacts; both ET and $\mathrm{HT}$ are the highest in Moncofar for the first two years, for which the rest of impacts are very low as compared to those in Orihuela. It must be noted that CFs for toxicity impacts are subject to great uncertainty because methodologies are still under development; hence, HT and ET results have to be regarded with care. This emphasizes the importance of analysing other impact categories besides $\mathrm{CC}$ when evaluating the environmental sustainability of bioenergy feedstocks. The quantification of water use impacts is of high interest in the Mediterranean region of Spain, where water is a limited resource. In the same way as for green and blue water, it would be advisable to develop CFs at regional level for impact categories such as TA, FE or POF. These issues underline the importance of considering local aspects and casespecific conditions in order to understand the actual environmental benefits brought about by energy from biomass. Biophysical models that predict biomass productivity for different levels of nitrogen fertilization and nutrient use efficiency would be extremely helpful for the selection of production practices, in combination with LCA.

In addition to spatial variability and variability in management practices, impact results are subject to temporal variability. The frequency and intensity of the input application in perennial short-cycles can vary considerably from year to year, as well as the yields. This is why applying a multiyear perspective, in accordance with the putative lifetime of these crops, is strongly recommended to provide more accurate environmental results for perennial systems optimization. The bioenergy production represents a challenge for farmers in achieving high yields by means of long-term sustainable practices. In this study, LCA is proposed as a tool to assist farmers in the development of more sustainable farming systems, provided that their inherent variability is captured.

When intended for electricity generation, switchgrass must deliver substantial GHG savings throughout the life cycle. Under the proposed management plans, the feedstock produced in both Moncofar and Orihuela would be eligible for electricity generation in the EU, ideally after the full production capacity is reached. One of the greatest uncertainties involves the estimation of ILUC effects, which can reduce the GHG benefits from bioenergy. Switchgrass cultivation in marginal lands can contribute to minimize indirect emissions, provided that yields are high enough for the cost- 
effectiveness of the impact reduction relative to conventional energy sources. Further LCA case studies can also be of great support in the sustainability assessment of Mediterranean biomass feedstocks, with the ultimate goal of establishing certification schemes.

\section{Acknowledgements}

The research has been partially funded by the body Generalitat Valenciana through Fundación Agroalimed, under the coordination of the Valencian Institute for Agricultural Research (IVIA). The authors would like to acknowledge the cooperatives Sociedad exportación de agrios $N^{\circ} 2$ Coop. $V$. and Surinver for the guidance on the crop management.

\section{References}

[1] Eurostat. Supply, transformation and consumption of renewable energies - annual data 2016. Accessed at: http://ec.europa.eu/eurostat/en/web/products-datasets/INRG 107A (7 April 2016)

[2] IDAE. Instituto para la Diversificación y el Ahorro de Energía. Plan de Energías Renovables 2011-2020. Ministerio de Industria, Energía y Turismo. Madrid (Spain) 2011.

[3] Fischer G, Prieler S, van Velthuizen H, Berndes G, Faaij A, Londo M, et al. Biofuel production potentials in Europe: Sustainable use of cultivated land and pastures, Part II: Land use scenarios. Biomass Bioenerg, 34(2) (2010) 173-187.

[4] IEA. International Energy Agency. Technology Roadmap for Bioenergy for Heat and Power. Paris (France) 2012.

[5] Scarlat N, Dallemand JF, Monforti F, Nita V. The role of biomass and bioenergy in a future bioeconomy: Policies and facts. Env Dev, 15 (2015) 3-34.

[6] Heaton E, Voigt T, Long SP. A quantitative review comparing the yields of two candidate $\mathrm{C} 4$ perennial biomass crops in relation to nitrogen, temperature and water. Biomass Bioenerg, 27(1) (2004) 21-30.

[7] Somerville C, Youngs H, Taylor C, Davis SC, Long SP. Feedstocks for lignocellulosic biofuels. Sci, 329(5993) (2010) 790-792.

[8] Tilman D, Hill J, Lehman C. Carbon-negative biofuels from low-input high-diversity grassland biomass. Sci, 314(5805) (2006) 1598-1600.

[9] Lewandowski I, Scurlock JM, Lindvall E, Christou M. The development and current status of perennial rhizomatous grasses as energy crops in the US and Europe. Biomass Bioenerg, 25(4) (2003) 335-361.

[10] Byrt CS, Grof CP, Furbank RT. C4 Plants as biofuel feedstocks: optimising biomass production and feedstock quality from a lignocellulosic perspectivefree access. J Integr Plant Biol, 53(2) (2011) 120-135.

[11] Alexopoulou E, Zanetti F, Scordia D, Zegada-Lizarazu W, Christou M, Testa G, et al. Long-Term Yields of Switchgrass, Giant Reed, and Miscanthus in the Mediterranean Basin. Bioenerg Res, 8(4) (2015) 1492-1499. 
[12] Zhuang Q, Qin Z, Chen M. Biofuel, land and water: maize, switchgrass or Miscanthus? Env Res Lett, 8(1) (2013) 015020, 1-6; doi:10.1088/17489326/8/1/015020

[13] Alexopoulou E, Sharma N, Papatheohari Y, Christou M, Piscioneri I, Panoutsou C, et al. Biomass yields for upland and lowland switchgrass varieties grown in the Mediterranean region. Biomass Bioenerg, 32(10) (2008) 926-933.

[14] Monti A, Venturi P, Elbersen HW. Evaluation of the establishment of lowland and upland switchgrass (Panicum virgatum L.) varieties under different tillage and seedbed conditions in northern Italy. Soil Tillage Res, 63(1) (2001) 75-83.

[15] Monti A (Ed.) Switchgrass: A valuable biomass crop for energy. Springer Science \& Business Media. Berlin (Germany) 2012.

[16] Vadas PA, Barnett $\mathrm{KH}$, Undersander DJ. Economics and energy of ethanol production from alfalfa, corn, and switchgrass in the Upper Midwest, USA. Bioenerg Res, 1(1) (2008) 44-55.

[17] Sanderson MA, Schmer MR, Owens V, Keyser P, Elbersen W. Crop management of switchgrass. In: Springer Ed. Switchgrass, London (United Kingdom) 2012, pp. 87112.

[18] Skinner RH, Adler PR. Carbon dioxide and water fluxes from switchgrass managed for bioenergy production. Agric Ecosyst Env, 138(3) (2010) 257-264.

[19] Skinner RH, Zegada-Lizarazu W, Schmidt JP. Environmental impacts of switchgrass management for bioenergy production. In: Springer Ed. Switchgrass, London (United Kingdom) 2012, pp. 129-152.

[20] Monti A, Barbanti L, Zatta A, Zegada-Lizarazu W. The contribution of switchgrass in reducing GHG emissions. Gcb Bioenerg, 4(4) (2012) 420-434.

[21] Heller MC, Keoleian GA, Volk TA. Life cycle assessment of a willow bioenergy cropping system. Biomass Bioenerg, 25(2) (2003) 147-165.

[22] Smeets EM, Lewandowski IM, Faaij AP. The economic and environmental performance of miscanthus and switchgrass production and supply chains in a European setting. Renew Sustain Energy Rev, 13(6) (2009) 1230-1245.

[23] Bai $Y$, Luo L, van der Voet E. Life cycle assessment of switchgrass-derived ethanol as transport fuel. Int J Life Cycle Assess, 15(5) (2010) 468-477.

[24] Cherubini F, Jungmeier G. LCA of a biorefinery concept producing bioethanol, bioenergy, and chemicals from switchgrass. Int J Life Cycle Assess, 15 (2010) 53-66.

[25] Sinistore JC, Reinemann DJ, Izaurralde RC, Cronin KR, Meier PJ, Runge TM, et al. Life cycle assessment of switchgrass cellulosic ethanol production in the Wisconsin and Michigan agricultural contexts. Bioenerg Res, 8(3) (2015) 897-909.

[26] Berger M, Pfister S, Bach V, Finkbeiner M. Saving the Planet's Climate or Water Resources? The Trade-Off between Carbon and Water Footprints of European Biofuels. Sustain, 7(6) (2015) 6665-6683; doi:10.3390/su7066665

[27] Chiu, YW, Suh S, Pfister S, Hellweg S, Koehler A. Measuring ecological impact of water consumption by bioethanol using life cycle impact assessment. Int J Life Cycle Assess, 17(1) (2012) 16-24. 
[28] Bessou C, Basset-Mens C, Tran T, Benoist A. LCA applied to perennial cropping systems: a review focused on the farm stage. Int J Life Cycle Assess, 18(2) (2013) 340-361.

[29] Fazio S, Monti A. Life cycle assessment of different bioenergy production systems including perennial and annual crops. Biomass Bioenerg, 35(12) (2011) 4868-4878.

[30] Schmidt T, Fernando AL, Monti A, Rettenmaier N. Life Cycle Assessment of bioenergy and bio-based products from perennial grasses cultivated on marginal land in the Mediterranean Region. Bioenerg Res, 8(4) (2015) 1548-1561.

[31] Gathorne-Hardy A, Reddy DN, Venkatanarayana M, Harriss-White B. System of Rice Intensification provides environmental and economic gains but at the expense of social sustainability—A multidisciplinary analysis in India. Agric Syst, 143 (2016) 159168.

[32] González-García S, Bacenetti J, Negri M, Fiala M, Arroja L. Comparative environmental performance of three different annual energy crops for biogas production in Northern Italy. J Clean Prod, 43 (2013) 71-83.

[33] González-García S, Baucells F, Feijoo G, Moreira, MT. Environmental performance of sorghum, barley and oat silage production for livestock feed using life cycle assessment. Resour Conserv Recycl, 111 (2016) 28-41.

[34] Ribal J, Ramírez-Sanz C, Estruch V, Clemente G, Sanjuán N. Organic versus conventional citrus. Impact assessment and variability analysis in the Comunitat Valenciana (Spain). Int J Life Cycle Assess, (2016); doi: 10.1007/s11367-016-1048-2

[35] Vázquez-Rowe I, Villanueva-Rey P, Moreira MT, Feijoo G. Environmental analysis of Ribeiro wine from a timeline perspective: harvest year matters when reporting environmental impacts. J Environ Manag, 98 (2012) 73-83.

[36] Boone L, De Meester S, Vandecasteele B, Muylle H, Roldán-Ruiz I, Nemecek T, Dewulf J. Environmental life cycle assessment of grain maize production: An analysis of factors causing variability. Sci Total Environ, 553 (2016) 551-564.

[37] Cerutti AK, Beccaro GL, Bruun S, Bosco S, Donno D, Notarnicola B, et al. Life cycle assessment application in the fruit sector: state of the art and recommendations for environmental declarations of fruit products. J Clean Prod, 73 (2014) 125-135.

[38] Vinyes E, Gasol CM, Asin L, Alegre S, Muñoz P. Life Cycle Assessment of multiyear peach production. J Clean Prod, 104 (2015) 68-79.

[39] Chueca P, Moltó E. Proyecto de evaluación de cultivos energéticos lignocelulósicos en la Comunidad Valenciana. Agric Coop, 328 (2012) 13-16.

[40] USDA. United States Department of Agriculture. Soil Conservation Service. Soil Mechanics Level 1-USDA textural soil classification 1987. Accessed at: http://www.wcc.nrcs.usda.gov/ftpref/wntsc/H\&H/training/soilsOther/soil-USDA-texturalclass.pdf (19 January 2017)

[41] IVIA. Instituto Valenciano de Investigaciones Agrarias. Meteorología-Datos Meteorológicos 2015. Accessed at: http://riegos.ivia.es/datos-meteorologicos (3 December 2015) 
[42] Gasol CM, Gabarrell X, Anton A, Rigola M, Carrasco J, Ciria P, Solano ML, Rieradevall, J. Life cycle assessment of a Brassica carinata bioenergy cropping system in southern Europe. Biomass Bioenerg, 31(8) (2007) 543-555.

[43] Kaltschmitt M, Reinhardt GA, Stelzer T. Life cycle analysis of biofuels under different environmental aspects. Biomass Bioenerg, 12(2) (1997) 121-134.

[44] Monti A, Fazio S, Venturi G. Cradle-to-farm gate life cycle assessment in perennial energy crops. Eur J Agron, 31(2) (2009) 77-84.

[45] Barro R, Ciria P, Pérez J, Chueca P, Fernández M, Carrasco J. Combustion properties of switchgrass grown under Mediterranean environments. Biomass Bioenerg, (2017) (under review).

[46] Frischknecht R, Althaus HJ, Bauer C, Doka G, Heck T, Jungbluth N, et al. The environmental relevance of capital goods in life cycle assessments of products and services. Int J Life Cycle Assess, 12(1) (2007) 7-17.

[47] Sastre CM, Maletta E, González-Arechavala Y, Ciria P, Santos AM, del Val A. et al. Centralised electricity production from winter cereals biomass grown under centralnorthern Spain conditions: Global warming and energy yield assessments. Appl Energy, 114 (2014) 737-748.

[48] Maletta E, Salvadó A, Rovira L, Tascón J, Chueca P, López F, et al. Switchgrass variety trials in 4 locations of Spain: results from 2 years evaluation in experimental plots with upland and lowland ecotypes. $20^{\text {th }}$ European Biomass Conference and Exhibition, Milan (Italy), 18-22 June 2012.

[49] Wernet G, Bauer C, Steubing B, Reinhard J, Moreno-Ruiz E, Weidema B. The ecoinvent database version 3 (part I): overview and methodology. Int $\mathrm{J}$ Life Cycle Assess, 21(9) (2016) 1218-1230.

[50] Audsley E, Alber S, Clift R, Cowell S, Crettaz P, Gaillard G, et al. Harmonisation of environmental life cycle assessment for agriculture. Final Report. Concerted action AIR3-CT94-2028. European Commission DGVI Agriculture, Brussels (Belgium) 2003.

[51] Nemecek T, Kägi T. Life cycle inventories of agricultural production systems, data v2. 0, Ecoinvent report No 15a. Swiss Centre for Life Cycle Inventories. Dübendorf (Switzerland) 2007.

[52] PE International. Gabi software and database: contents for Life Cycle Engineering. Stuttgart (Germany) 2014.

[53] Berthoud A, Maupu P, Huet C, Poupart A. Assessing freshwater ecotoxicity of agricultural products in life cycle assessment (LCA): a case study of wheat using French agricultural practices databases and USEtox model. Int $\mathrm{J}$ Life Cycle Assess, 16(8) (2011) 841-847.

[54] Lewis KA, Green A, Tzilivakis J, Warner D. The Pesticide Properties DataBase (PPDB) developed by the Agriculture \& Environment Research Unit (AERU), University of Hertfordshire, Hatfield (United Kingdom) 2015.

[55] EMEP/EEA. Air pollutant emission inventory guidebook 2013. EEA Technical report No 12/2013. Accessed at: http://www.eea.europa.eu/publications/emep-eeaquidebook-2013 (27 August 2015) 
[56] IPCC. Intergovernmental Panel on Climate Change. Guidelines for national greenhouse gas inventories. Agriculture, forestry and other land use vol. 4. Geneva (Switzerland) 2006.

[57] Nemecek T, Schnetzer J, Reinhard J. Updated and harmonised greenhouse gas emissions for crop inventories. Int J Life Cycle Assess, 21 (2016) 1361-1378.

[58] Faist-Emmenegger M, Reinhard J, Zah R. Sustainability quick check for biofuelsintermediate background report. EMPA, Dübendorf (Switzerland) (2009), pp. 129. Accessed at: www.sqcb.org (27 December 2016)

[59] de Willigen P. An analysis of the calculation of leaching and denitrification losses as practised in the NUTMON approach. Report 18. Plant Research International, Wageningen (The Netherlands) 2000.

[60] Lerkkasemsan N, Achenie LE. Life cycle costs and life cycle assessment for the harvesting, conversion, and the use of switchgrass to produce electricity. Int J Chem Eng (2013) Article ID 492058, 1-16; doi: http://dx.doi.org/10.1155/2013/492058

[61] Goedkoop M, Heijungs R, Huijbregts M, Schryver A, Struijs J, van Zelm R. ReCiPe: a lifecycle impact assessment method which comprises harmonised category indicators at the midpoint and the endpoint level; First edition (revised); Report I: Characterisation, May 2013. Accessed at: http://www.lcia-recipe.net (4 July 2016)

[62] Rosenbaum RK, Bachmann TM, Gold LS, Huijbregts MA, Jolliet O, Juraske R, et al. USEtox-the UNEP-SETAC toxicity model: recommended characterisation factors for human toxicity and freshwater ecotoxicity in life cycle impact assessment. Int J Life Cycle Assess, 13(7) (2008) 532-546.

[63] Hospido A, Núñez M, Antón A. Irrigation mix: how to include water sources when assessing freshwater consumption impacts associated to crops. Int J Life Cycle Assess, 18(4) (2013) 881-890.

[64] Milà i Canals LM, Chenoweth J, Chapagain A, Orr S, Antón A, Clift R. Assessing freshwater use impacts in LCA: Part I-inventory modelling and characterisation factors for the main impact pathways. Int J Life Cycle Assess, 14(1) (2009) 28-42.

[65] Núñez M, Pfister S, Antón A, Muñoz P, Hellweg S, Koehler A, et al. Assessing the environmental impact of water consumption by energy crops grown in Spain. J Ind Ecol, 17(1) (2012) 90-102.

[66] MAGRAMA. Ministerio de Agricultura, Alimentación y Medio Ambiente. Anuario de estadística agraria. Madrid (Spain) 2014. Accessed at: http://www.magrama.gob.es/es/estadistica/temas/ (15 August 2015)

[67] Berg, WA. Response of a mixed native warm-season grass planting to nitrogen fertilization. J Range Manag, 48 (1995) 64-67.

[68] Mann JJ, Barney JN, Kyser GB, Di Tomaso JM. Root system dynamics of Miscanthus $\times$ giganteus and Panicum virgatum in response to rainfed and irrigated conditions in California. Bioenerg Res, 6(2) (2013) 678-687.

[69] European Commission. Report from the Commission to the Council and the European Parliament on sustainability requirements for the use of solid and gaseous biomass sources in electricity, heating and cooling. Brussels (Belgium) 2010. Accessed 
at: http://eur-lex.europa.eu/legal-content/EN/TXT/?uri=CELEX\%3A52010DC0011

March 2016)

[70] Sastre CM, González-Arechavala Y, Santos, AM. Global warming and energy yield evaluation of Spanish wheat straw electricity generation-A LCA that takes into account parameter uncertainty and variability. Appl Energy, 154 (2015) 900-911.

[71] Guretzky JA, Biermacher JT, Cook B, Kering M., Mosali J. Switchgrass for forage and bioenergy: harvest and nitrogen rate effects on biomass yields and nutrient composition. Plant Soil, 339 (2011) 69; doi:10.1007/s11104-010-0376-4

[72] Butnar I, Rodrigo J, Gasol CM, Castells F. Life-cycle assessment of electricity from biomass: Case studies of two biocrops in Spain. Biomass Bioenerg 34(12) (2010) 1780-1788.

[73] Kim S, Dale BE. Cumulative energy and global warming impact from the production of biomass for biobased products. J Ind Ecol, 7(3-4) (2003) 147-162.

[74] Ridoutt BG, Pfister S. A revised approach to water footprinting to make transparent the impacts of consumption and production on global freshwater scarcity. Glob Env Chang, 20(1) (2010) 113-120. 